\title{
INFLUENCE OF GROWTH RETARDANT ON GROWTH AND DEVELOPMENT OF Euphorbia pulcherrima Willd. ex Klotzsch
}

\author{
Anna Pobudkiewicz \\ Research Institute of Horticulture, Konstytucji 3 Maja 1/3, 96-100 Skierniewice, Poland \\ e-mail: Anna.Pobudkiewicz@inhart.pl
}

Received: 28.02 .2014

\begin{abstract}
This study was undertaken to evaluate the influence of single foliar flurprimidol treatment on morphology and transpiration of 'Roman' and 'Freedom Red' poinsettias. The growth retardant flurprimidol (Topflor 015 SL) was applied once as a foliar spray at concentrations of 5,10 or $15 \mathrm{mg} \times \mathrm{dm}^{-3}$ when lateral shoots were about $5 \mathrm{~cm}$ in length. Single foliar flurprimidol treatment was sufficient to inhibit stem elongation of both poinsettia cultivars. The degree of growth inhibition depended on cultivar and growth retardant concentration. As compared to the control, the shoots of flurprimidol treated 'Roman' and 'Freedom Red' plants were up to $44 \%$ and $37 \%$ shorter, respectively. The desirable plant heights for 'Roman' and 'Freedom Red' poinsettias were obtained with flurprimidol at concentrations of 5 and $10 \mathrm{mg}$ $\times \mathrm{dm}^{-3}$, respectively. The shoots of flurprimidol sprayed poinsettia were also more rigid and aligned relative to each other and thus the bracts on the plant were placed on the same level. The diameters of growth retardant treated poinsettias were up to $13 \%$ narrower. The leaf areas, petiole lengths, fresh and dry weights of 'Roman' and 'Freedom Red' poinsettias treated with flurprimidol were substantially smaller as compared to the control. The bract diameters of both poinsettia cultivars were only slightly affected by growth retardant application. Plants exposed to flurprimidol had also intensified green leaf pigmentation. There was almost no abscission of the oldest leaves in the low portions of growth retardant treated plants, compared to those of the control ones. Flurprimidol had no effect on transpiration rate per unit leaf area and stomatal conductance in both poinsettia cultivars. No phytotoxicity was observed in flurprimidol treated plants. Chemical name used: $\alpha$-(1-methylethyl)- $\alpha$-[4-(trifluromethoxy)phenyl]5-pyrimidinemethanol (flurprimidol).
\end{abstract}

Key words: poinsettia; growth inhibition; flurprimidol; stomatal conductance; transpiration

\section{INTRODUCTION}

The poinsettia (Euphorbia pulcherrima Willd. ex Klotzsch), a member of the large and diverse fam- ily Euphorbiaceae, originated in southern Mexico and northern Guatemala. Nowadays, it is a very popular and economically highly significant potted plant in Europe, Asia, Australia, and North America. Poinsettias generally grow too tall in a greenhouse without some method of height control. There are numerous environmental, cultural and genetic methods available to obtain short and well compact poinsettia. The final height can be controlled genetically by selecting cultivars that have short internodes. Plant morphology can be controlled environmentally by the difference (DIF) between day temperature (DT) and night temperature (NT). Poinsettia stem elongation is inhibited by higher night temperatures than day temperatures - negative DIF (-DIF = DT < NT) [1]. However, the most common cultural method of controlling poinsettia height is the application of growth retardants [2-4]. The use of these compounds is the fastest and cheapest way to impact the size and aesthetic quality of finished plants. The effect of growth retardant treatment depends on many factors, but the most important is the chemical dose which may vary by cultivar and location. For example, relatively small concentrations of daminozide $\left(1250 \mathrm{mg} \times \mathrm{dm}^{-3}\right)$ and chlormequat chloride $(750 \mathrm{mg} \times$ $\mathrm{dm}^{-3}$ ) were used to inhibit stem elongation of 'Freedom Salmon' and 'Classic Red' poinsettias [5], in contrast to 'Freedom Red', 'Success Red', and 'Winter Rose Dark Red' poinsettias which required much higher concentrations of daminozide $\left(4500 \mathrm{mg} \times \mathrm{dm}^{-3}\right)$ and chlormequat chloride $\left(1500 \mathrm{mg} \times \mathrm{dm}^{-3}\right)$ to inhibit the height [2]. These results, obtained in the United States of America, indicate that the response of 'Freedom' poinsettia to growth retardant foliar sprays also varied by location. Optimal rates were substantially lower for Indiana [5] than for South Carolina [2]. There are several growth retardants which were used to inhibit the elongation of poinsettia shoots, e.g. paclobutrazol $[3,4]$, 
uniconazole [6], daminozide, and chlormequat chloride [7], but to date only one literature source reported on the impact of foliar flurprimidol treatment on poinsettia height. Flurprimidol, applied as a foliar spray, has been reported to suppress stem elongation of 'Eckespoint C-1 Red', 'Annette Hegg Dark Red' and 'Gutbier V-14 Glory' poinsettias [8], but it has not been used to control the plant growth of 'Roman' and 'Freedom Red' poinsettias. In this study, flurprimidol was chosen for poinsettia height control due to its prolonged effect following a single application at very low doses. Flurprimidol, like other pyrimidine or triazole derivatives, reduces shoot length primarily by limiting cell division and extension in the subapical meristematic zone of the stem [9]. Flurprimidol inhibits the endogenous formation of gibberellins by blocking cytochrome P-450-type oxygenases that catalyze the reactions between ent-kaurene and ent-kaurenoic acid [10], thereby inhibiting the elongation of plant cells. The growth retarding activity of flurprimidol is relatively high in a broad spectrum of ornamental plant species [11-15].

Poinsettia has a high demand for water and transpires a lot of water. The quantity of water transpired by plants might depend on the size and number of their leaves. Poinsettias with small leaves transpire less intensively relative to cultivars with large leaves. There are reports which indicate that growth retardants might also reduce transpiration in some plants [16,17], but there is no information concerning the impact of flurprimidol on transpiration in poinsettia and other ornamental pot plants. Due to the lack of such information, an attempt was made to examine the influence of flurprimidol on poinsettia transpiration. The aim of this study was to evaluate the influence of single foliar flurprimidol application on morphology and transpiration of 'Roman' and 'Freedom Red' poinsettias.

\section{MATERIALS AND METHODS}

The study was conducted in a glass greenhouse during 2009 and 2010. Well-rooted cuttings of 'Roman' and 'Freedom Red' poinsettias, obtained from a commercial source, were potted individually into $12 \mathrm{~cm}$ pots and placed on greenhouse benches. The pots were filled with commercial substrate TS2 amended with Osmocote Exact $\left(4 \mathrm{~g} / \mathrm{dm}^{-3}\right.$ of substrate). Six days after planting, the poinsettia upper nodes were removed leaving 4 leaves on the remaining plant. Prior to flurprimidol treatment, poinsettias were selected for uniformity. The growth retardant was used when lateral shoots following pinching were about $5 \mathrm{~cm}$ in length. Early in the morning, flurprimidol (Topflor 015 SL) was applied as a single foliar spray at concentrations of 5 , 10 and $15 \mathrm{mg} \times \mathrm{dm}^{-3}$. At the same time, the control plants were sprayed with tap water. No surfactant was added to the growth retardant spray solutions. Hand sprayers were used for flurprimidol spray treatments. The plants were sprayed until the whole plant surface was thoroughly covered with the growth retardant spray solution, but the solution was not allowed to drip from the leaves into the substrate. The plants were grown under natural photoperiod and the temperature in the greenhouse was maintained between $20-24^{\circ} \mathrm{C}$ during the day. During the experiment, the photoperiod ranged from 17 hours at the beginning to 8 hours at the end and the light intensity measured at the plant canopy level ranged from 37 to $780 \mu \mathrm{mol} \mathrm{m}^{-2} \mathrm{~s}^{-1}$. The experiment was carried out from July to December. Standard cultivation practices, including fertilizing, were applied.

At the stage of visible anthesis (first pollen shed) of two branches, the following morphological parameters were recorded: shoot length, plant width (determined by averaging two perpendicular measurements of the plant), bract diameter of each flowering stem (the bract diameter was calculated as the average from the widest diameter and diameter $90^{\circ}$ across), petiole length and leaf area (determined by using a stationary Delta-T planimeter (Device LTD., Cambridge, UK). The physiological parameters, such as stomatal conductance $\left(\mathrm{g}_{\mathrm{s}}\right)$ and transpiration $(\mathrm{T})$, were monitored at midday on attached, fully expanded leaves, using the LI-1600 Steady Porometer from Li-COR. At the end of the experiment, the whole plants were cut off just above the substrate surface in order to determine their fresh weight. After that, the plants were dried at $70^{\circ} \mathrm{C}$ until they reached a constant mass to determine dry weights.

The experiment was arranged as a randomized complete block design with three replications per treatment. The experimental data were subjected to an analysis of variance. The Duncan's Multiple Range Test at a 5\% level of significance was used for mean separation. The values of $\mathrm{p}=0.05$ were considered to be statistically significant. All statistical analyses were performed with Statistica package, version 10 [18].

\section{RESULTS}

The effects of flurprimidol on morphological and physiological traits of 'Roman' and 'Freedom Red' poinsettias were similar in two growing seasons (2009-2010).

\section{Effect of flurprimidol on morphological characteristics}

Single foliar flurprimidol treatment was sufficient to inhibit stem elongation of both poinsettia cultivars (Fig. 1). All growth retardant treated plants were substantially shorter than the untreated ones and those differences were statistically significant. The degree of growth inhibition depended on flurprimidol concentra- 
tion. Both in 'Roman' and 'Freedom Red' plants, shoot length was reversely proportional to growth retardant doses. Relative to the untreated plants, flurprimidol at a concentration of $5 \mathrm{mg} \times \mathrm{dm}^{-3}$, applied to 'Roman' and 'Freedom Red' poinsettias resulted, in 29\% and 22\% shorter shoots, respectively. The higher growth retardant concentrations resulted in further inhibition of stem elongation of both cultivars. The shoots of 'Roman' and 'Freedom Red' plants treated with flurprimidol at $15 \mathrm{mg} \times \mathrm{dm}^{-3}$ (the highest concentration) were $44 \%$ and $37 \%$ shorter, respectively, as compared to the control. The desirable shoot length $(16-18 \mathrm{~cm})$ for 'Roman' was obtained with the lowest growth retardant concentration $\left(5 \mathrm{mg} \times \mathrm{dm}^{-3}\right)$, but a higher flurprimidol concentration $\left(10 \mathrm{mg} \times \mathrm{dm}^{-3}\right)$ was required for 'Freedom Red'. There were no significant differences in shoot length between the tested cultivars, but shoots of growth retardant treated 'Roman' were slightly shorter than shoots of 'Freedom Red'. Shoots of flurprimidol sprayed poinsettia were not only shorter and more rigid but also aligned relative to each other and thus the bracts on the plant were placed on the same level.

The bract diameters of both poinsettia cultivars were only slightly affected by flurprimidol application (Fig. 2). The bract diameters of 'Roman' and 'Freedom Red' plants sprayed with the highest retardant concentration $\left(15 \mathrm{mg} \times \mathrm{dm}^{-3}\right)$ were only $9 \%$ smaller than those of the control plants.

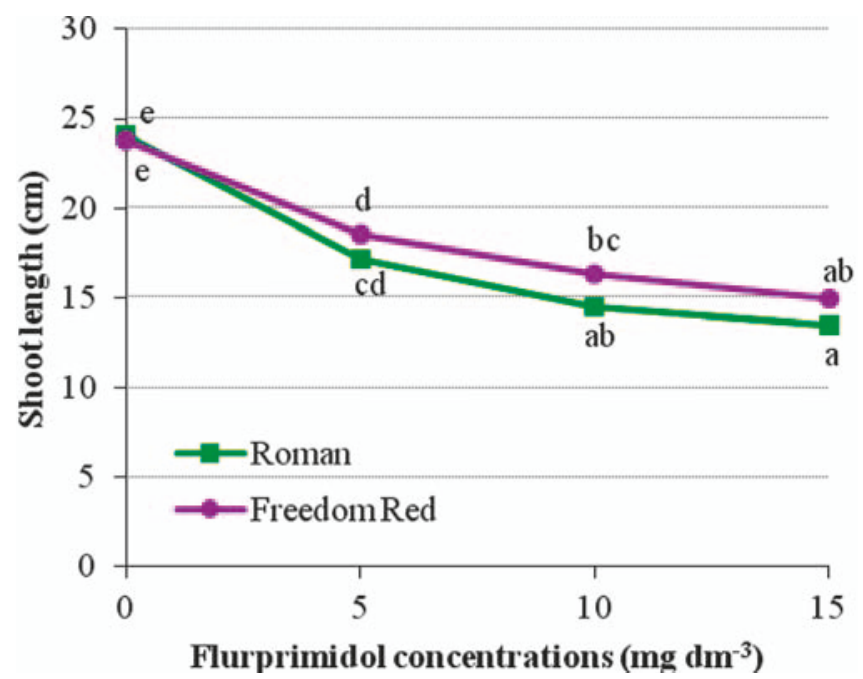

Fig. 1. Shoot lengths of 'Roman' and 'Freedom Red' poinsettias as affected by flurprimidol applied as single foliar spray. Data averaged over two growing seasons. The means indicated by the same letter do not differ significantly at $\mathrm{p}=0.05$, according to Duncan's Multiple Range Test.

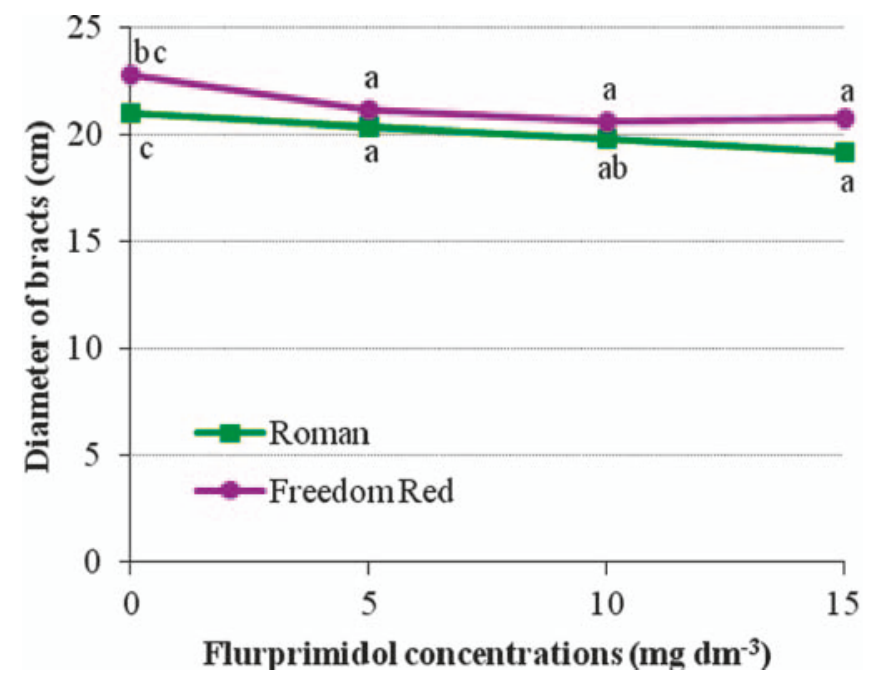

Fig. 2. Effect of flurprimidol applied as single foliar spray on bract diameter of 'Roman' and 'Freedom Red' poinsettias. Data averaged over two growing seasons. The means indicated by the same letter do not differ significantly at $p=0.05$, according to Duncan's Multiple Range Test. 
The growth parameters other than shoot length and bract diameter were also affected by chemical treatment. The widths of flurprimidol treated 'Roman' and 'Freedom Red' plants were smaller compared to the untreated ones (Fig. 3). The growth retardant at $5 \mathrm{mg} \times \mathrm{dm}^{-3}$ reduced the diameters of 'Roman' and 'Freedom Red' by $6 \%$ and 5\%, respectively. Poinsettias sprayed with flurprimidol at $15 \mathrm{mg} \times \mathrm{dm}^{-3}$ were up to $13 \%$ narrower relative to the control.

The growth retardant also had an apparent effect on poinsettia leaf area. There were significant differences in leaf area between control plants and poinsettias treated with the growth retardant at concentrations of 5-15 mg $\times \mathrm{dm}^{-3}$ (Fig.4A). The leaves of 'Roman' and 'Freedom Red' poinsettias treated with flurprimi- dol at $5 \mathrm{mg} \times \mathrm{dm}^{-3}$ were $29 \%$ and $21 \%$ smaller, respectively, than those of the untreated plants. In 'Roman' the higher retardant doses did not result in a further significant reduction in leaf area, but in 'Freedom Red' the leaf area was retarded with increasing flurprimidol concentrations up to $15 \mathrm{mg} \times \mathrm{dm}^{-3}$. The leaf areas of 'Roman' and 'Freedom Red' plants treated with the retardant at $15 \mathrm{mg} \times \mathrm{dm}^{-3}$ were $34 \%$ and $33 \%$ smaller, respectively, relative to the control plants. Plants exposed to flurprimidol had also intensified green leaf pigmentation. There was almost no abscission of the oldest leaves in the low portions of growth retardant treated plants compared to the untreated ones. No phytotoxicity or malformations were observed in flurprimidol treated poinsettias.

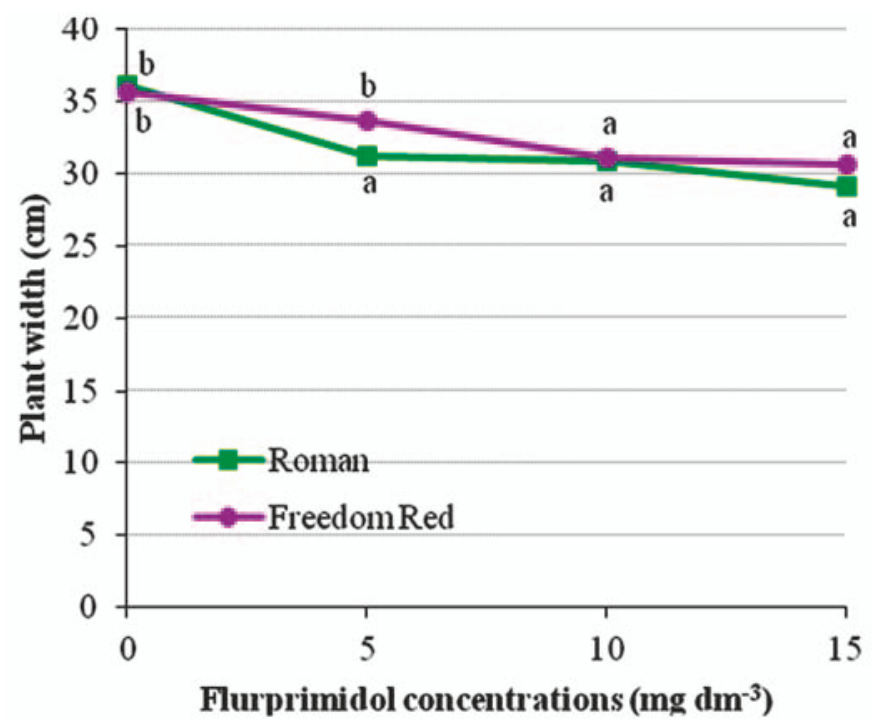

Fig. 3. Effect of flurprimidol applied as single foliar spray on plant width of 'Roman' and 'Freedom Red' poinsettias. Data averaged over two growing seasons. The means indicated by the same letter do not differ significantly at $\mathrm{p}=0.05$, according to Duncan's Multiple Range Test.

Petiole length was also affected by the tested chemical (Fig. 4B). Petioles of both cultivars were retarded with increasing growth retardant concentrations up to $10 \mathrm{mg} \times \mathrm{dm}^{-3}$, but the higher concentration $\left(15 \mathrm{mg} \times \mathrm{dm}^{-3}\right)$ caused no additional statistically significant retarding effect, compared to flurprimidol at $10 \mathrm{mg}$ $\times \mathrm{dm}^{-3}$. Relative to the controls, the retardant applied at $5 \mathrm{mg} \times \mathrm{dm}^{-3}$ to 'Roman' and 'Freedom Red' plants resulted in $35 \%$ and $20 \%$ shorter petioles, respectively. Flurprimidol at $10 \mathrm{mg} \mathrm{dm}^{-3}$ reduced the petiole length of 'Roman' and 'Freedom Red' poinsettias by $43 \%$ and $33 \%$, respectively. There were substantial differences in petiole lengths between poinsettia cultivars. Petioles of flurprimidol treated 'Roman' plants were shorter than those of similar plants of cv. 'Freedom Red'.

Both fresh (Fig. 5A) and dry (Fig. 5B) weights of 'Roman' and 'Freedom Red' poinsettias, sprayed with flurprimidol at 5-15 $\mathrm{mg} \times \mathrm{dm}^{-3}$, were significantly lower than those of the untreated ones. In both cultivars, the fresh (Fig. 5A) and dry (Fig. 5B) weights were reduced with increasing growth retardant concentrations up to $10 \mathrm{mg} \times \mathrm{dm}^{-3}$, but the higher concentration $\left(15 \mathrm{mg} \times \mathrm{dm}^{-3}\right)$ caused no additional statistically significant reducing effect, compared to flurprimidol at $10 \mathrm{mg} \mathrm{dm}^{-3}$. Relative to the control, the fresh weights of 'Roman' and 'Freedom Red' poinsettias sprayed with flurprimidol at $5 \mathrm{mg} \mathrm{dm}^{-3}$ were reduced by $28 \%$ and $23 \%$, respectively. The growth retardant at $10 \mathrm{mg}$ $\times \mathrm{dm}^{-3}$ decreased the fresh weights up to $37 \%$ in both poinsettia cultivars. Compared to the untreated plants, flurprimidol at the lowest concentration reduced the dry weights of 'Roman' and 'Freedom Red' up to $31 \%$ and $27 \%$, respectively. The growth retardant at $10 \mathrm{mg}$ $\mathrm{dm}^{-3}$ reduced the dry weights of 'Roman' and 'Freedom 
Red' poinsettias by $42 \%$ and $38 \%$, respectively. There were also differences in fresh and dry matters between the tested cultivars. The fresh and dry weights of 'Ro- man' plants treated with flurprimidol at $5-15 \mathrm{mg} \times \mathrm{dm}^{-3}$ were lowetr than those of similar plants of cv. 'Freedom Red'.
$\mathbf{A}$

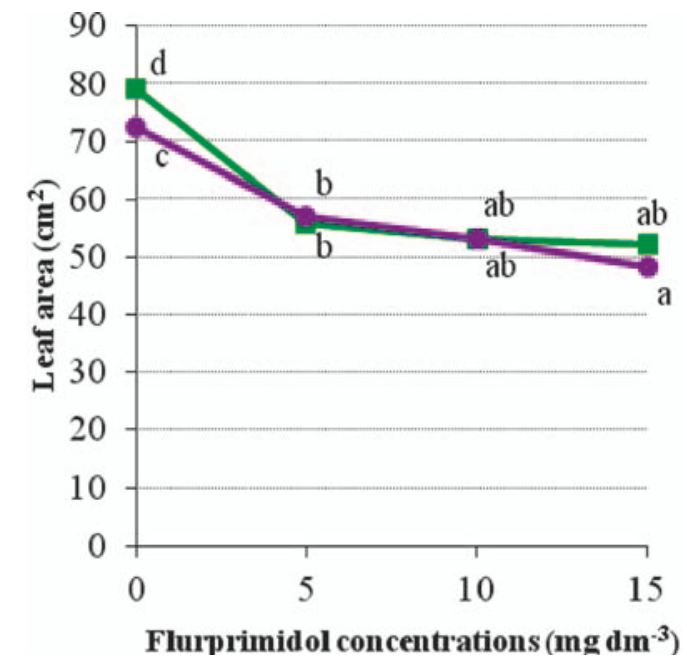

B

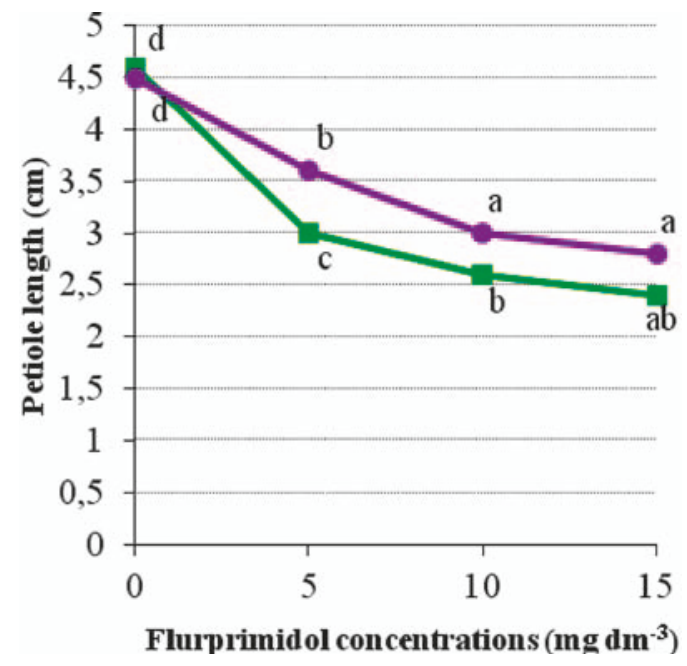

Fig. 4. Effect of flurprimidol applied as single foliar spray on leaf area (4A) and petiole length (4B) of 'Roman' and 'Freedom Red' poinsettias. Data averaged over two growing seasons. The means indicated by the same letter do not differ significantly at $\mathrm{p}=0.05$, according to Duncan's Multiple Range Test.

$\mathbf{A}$

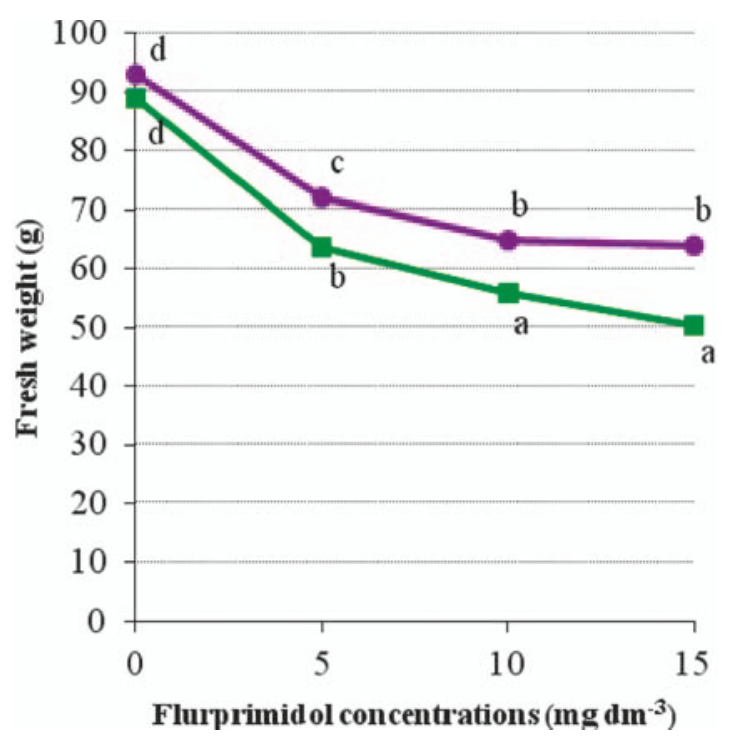

Roman
B

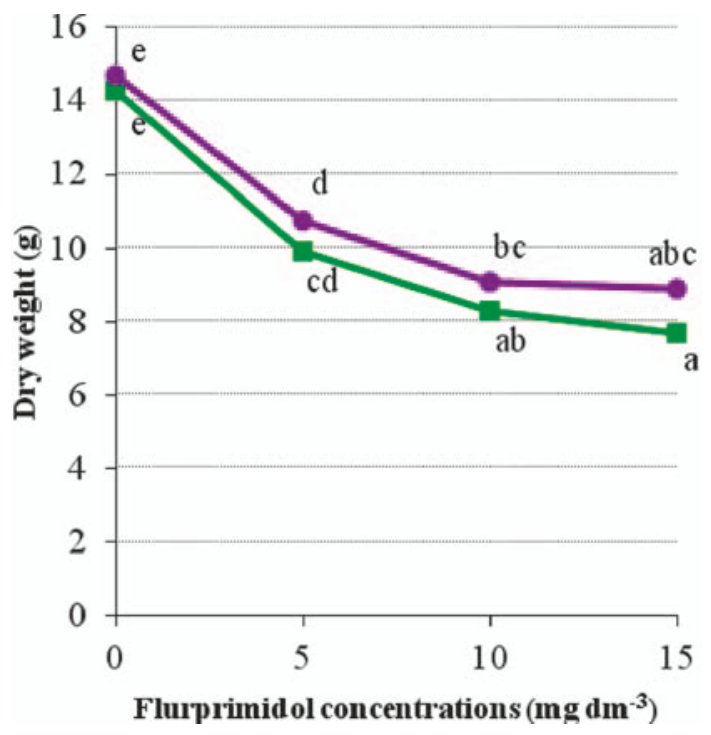

Freedom Red

Fig. 5. Fresh (A) and dry (B) weights of 'Roman' and 'Freedom Red' poinsettias as affected by flurprimidol applied as single foliar spray. Data averaged over two growing seasons. The means indicated by the same letter do not differ significantly at $\mathrm{p}=0.05$, according to Duncan's Multiple Range Test. 


\section{Effect of flurprimidol on} physiological characteristics

Relative to the control, the growth retardant at all concentrations $\left(5-15 \mathrm{mg} \times \mathrm{dm}^{-3}\right)$ did not influence leaf stomatal conductance of 'Roman' and 'Freedom Red' poinsettias (Table 1). Single growth retardant applications at $5-15 \mathrm{mg} \times \mathrm{dm}^{-3}$ also had no effect on transpiration rate per unit leaf area of both poinsettia cultivars (Table 1).

Table 1

Effect of flurprimidol on stomatal conductance $\left(\mathrm{g}_{\mathrm{s}}\right)$ and transpiration rate $(\mathrm{T})$ per unit leaf area of 'Roman' and 'Freedom Red' poinsettias. Data averaged over two growing seasons

\begin{tabular}{ccccc}
\hline \multirow{2}{*}{$\begin{array}{c}\text { Flurprimidol concentrations } \\
\left(\mathrm{mg} \times \mathrm{dm}^{-3}\right)\end{array}$} & \multicolumn{2}{c}{$\mathrm{g}_{\mathrm{s}}\left(\mathrm{mmol} \times \mathrm{m}^{-2} \mathrm{~s}^{-1}\right)$} & \multicolumn{2}{c}{$\mathrm{T}\left(\mathrm{mmol} \times \mathrm{m}^{-2} \mathrm{~s}^{-1}\right)$} \\
\cline { 2 - 5 } Control & 'Roman' & 'Freedom Red' & 'Roman' & 'Freedom Red' \\
5 & $64.63 \mathrm{ab}$ & $62.8 \mathrm{ab}$ & $1.05 \mathrm{ab}$ & $1.026 \mathrm{a}$ \\
10 & $66.09 \mathrm{ab}$ & $82.1 \mathrm{c}$ & $1.07 \mathrm{ab}$ & $1.361 \mathrm{~b}$ \\
15 & $77.60 \mathrm{bc}$ & $61.6 \mathrm{a}$ & $1.27 \mathrm{ab}$ & $0.905 \mathrm{a}$ \\
\hline
\end{tabular}

The means followed by the same letter do not differ significantly at $\mathrm{p}=0.05$, according to Duncan's Multiple Range Test.

\section{DISCUSSION}

Some researchers suggest that, compared with foliar sprays, growth retardants applied as substrate drenches provide more uniform growth control over a longer duration. For this reason, in most cases, growth retardants in poinsettia cultivation have been applied as substrate drenches $[3-5,7,19,20]$. The results presented in this paper demonstrate that flurprimidol, when applied as foliar spray, proved to be very effective in restricting shoot length of 'Roman' and 'Freedom Red' poinsettias over a long period and the final heights of those plants were very uniform. This is consistent with the results obtained for many other ornamental plant species grown in pots $[13,15,21-27]$. In all those experiments, different growth retardants applied as foliar sprays, at appropriate doses and at the optimum plant growth stages, provided plants with very uniform final heights.

The study reported here shows that growth retardant doses should be differentiated depending on poinsettia cultivar. 'Roman' plants required a lower flurprimidol concentration than 'Freedom Red' in order to achieve the desirable shoot length. This concurs with the results obtained by Currey and Lopez [5] who observed differences between poinsettia cultivars regarding the need for height control. These authors showed that 'Classic Red' required a much higher dose of flurprimidol, applied as substrate drench, when compared with 'Freedom Salmon'. Other authors have also reported that chemical doses should be varied with poinsettia cultivar. S a nders on et al. [20] demonstrated that flurprimidol, applied as substrate drench at $0.25 \mathrm{mg} / \mathrm{pot}$, substantially restricted the final heights of 'V-14 Glory' and 'Topstar' poinsettias but had no effect on the height of 'C-1 Red'.

In this experiment, conducted in Poland, the flurprimidol concentrations used for proper shoot length control of 'Roman' and 'Freedom Red' plants were very low $\left(5,10 \mathrm{mg} \times \mathrm{dm}^{-3}\right)$ in contrast to other poinsettia cultivars. For example, M c D a n i e 1 [8] showed in a study carried out in the USA that 'Eckespoint C-1 Red', 'Annette Hegg Dark Red' and 'Gutbier V-14 Glory' poinsettias required a few times higher flurprimidol concentration $\left(25 \mathrm{mg} \times \mathrm{dm}^{-3}\right)$ in order to achieve the desirable plant height [8]. The difference in growth retardant doses used could result from two reasons. Firstly, 'Roman' and 'Freedom Red' poinsettias might be very sensitive to flurprimidol spray treatment. Secondly, this may be due to a different location, Poland and Tennessee in the USA.

In the study presented here the shoots of flurprimidol treated poinsettia were not only short but also aligned relative to each other. As a result, all bracts on the plant were placed on this same level, which greatly increased plant quality.

The results reported here indicate that flurprimidol only slightly affected (up to 9\%) the bract diameter of 'Roman' and 'Freedom Red' poinsettias. In contrast, a large reduction in bract area (up to 49\%) was observed in poinsettia treated with flurprimidol as a substrate drench [5]. The authors also reported that the size of bracts in growth retardant treated poinsettia was cultivar dependent. Flurprimidol applied as a substrate drench reduced the bract area index in 'Polly's Pink', Freedom Salmon', 'Orion' or 'Classic Red' poinsettias up to $23 \%, 25 \%, 28 \%$ or $49 \%$, respectively. Other growth retardants have also been reported to diminish poinsettia bract area. For example, $\mathrm{Ni}$ u et al. [3] have shown that the bract area diminished by $20 \%$ in paclobutrazol treated 'Freedom' poinsettia. The bract area of 'Christmas Feelings' poinsettia decreased by about $40 \%$ and $27 \%$ following chlormequat chloride and daminozide application, respectively [7]. In the present study, although the bract diameter was smaller 
when 'Roman' and 'Freedom Red' poinsettias were treated with flurprimidol spray, the smaller bract diameter and suppressed plant height were proportional to each other. Therefore, the smaller bract diameter does not negatively impact the aesthetic quality of finished plants treated with flurprimidol spray.

The study reported here demonstrates that flurprimidol treatment produced shorter petioles resulting in a smaller plant diameter. This is consistent with the results obtained by Le wis et al. [2] who reported that daminozide and chlormequat chloride reduced petiole lengths in 'Dark Red', 'Success Red', 'Freedom Red' and 'Winter Rose' poinsettias. In the present experiment, thanks to shorter petioles and internodes, 'Roman' and 'Freedom Red' poinsettias were also more densely foliated.

As long as they inhibit poinsettia stem elongation, all growth retardants also affect the leaf area which can be reduced to a different extent. In this study, the leaf areas of 'Roman' and 'Freedom Red' poinsettias were reduced up to $34 \%$ depending on flurprimidol concentration. The leaf area of 'Christmas Feelings' poinsettia was reduced up to $10 \%$ by daminozide and chlormequat chloride [7]. A higher reduction in leaf area, up to $19 \%$, was found in 'Annette Hegg' poinsettia treated with ancymidol or chlormequat [19]. In the study presented here, although the leaf area decreased in flurprimidol treated 'Roman' and 'Freedom Red' poinsettias, the smaller leaf area and reduced plant height were proportional to each other.

Very often plants, treated with growth retardants also have darker green leaves. In this experiment, no data concerning the chlorophyll level were collected, but it was apparent that flurprimidol significantly intensified the dark green pigmentation in poinsettia leaves, which might be associated with higher chlorophyll content. There is no information about the impact of flurprimidol on the chlorophyll level in poinsettia leaves, but L od e t a et al. [7] reported that daminozide and chlormequat chloride enhanced the chlorophyll $a$ and chlorophyll $b$ contents in leaves of 'Christmas Feelings' poinsettia.

In the study reported here, in the low portions of flurprimidol sprayed 'Roman' and 'Freedom Red' poinsettias, the leaves were green and did not fall by the end of the production cycle, in contrast to the untreated plants where leaves turned yellow and very often fell off. Abscission of the oldest leaves, in the low portions of the control plants, resulted in an empty space between the pot rim and the first leaves on the plant, which greatly reduced the plant quality. There was no empty space between the pot rim and the first leaves in flurprimidol treated 'Roman' and 'Freedom Red' poinsettias. The absence of leaf abscission in growth retardant treated plants might be associated with higher contents of cytokinins [28] and polyamines [29]. Cytokinins and polyamines, such as spermine and spermidine, delay the aging of plants and this might be the reason why leaves in growth retardant treated plants do not fall and remain green for a longer duration compared to untreated plants. In this experiment, the absence of empty space between the pot rim and the first leaves on the plant in growth retardant treated 'Roman' and 'Freedom Red' poinsettias might also be due to the shortened lengths of the first internodes. Thanks to the very short first internodes, the leaves developed just above the pot rim.

The results presented in this paper demonstrate that flurprimidol did not affect transpiration rate per unit leaf area and stomatal conductance in 'Roman' and 'Freedom Red' poinsettias, which is consistent with some previous findings. Flurprimidol did not influence transpiration rates in Juglans nigra, Quercus palustris, Acer rubrum [30] and Forsythia spectabilis [31]. There are also reports which show that growth retardants reduced transpiration. For example, paclobutrazol decreased the transpiration rate in Catharanthus roseus (L.) G. Don. [32] and uniconazole reduced transpiration on a per leaf area basis in Hibiscus rosa-sinensis 'Ross Estey' [33] and in Dendranthema grandiflora Tzvelev 'Dalvina' [16]. Ancymidol was reported to reduce whole-plant transpiration of Euphorbia pulcherrima Wild 'Annette Hegg' [19]. In the present study, the absence of effect of growth retardant on transpiration rate per unit leaf area of 'Roman' and 'Freedom Red' poinsettias might be associated with the content of abscisic acid in plants. Abscisic acid is the hormone that triggers the closing of stomata when soil water is insufficient to keep up with transpiration. Flurprimidol decreased the levels of abscisic acid in Pseudotsuga menziesii [34] and Foeniculum sp. [35], whereas other growth retardants, which resulted in stomata closure, increased the levels of abscisic acid in olive trees [36] and apple seedlings [37]. Perhaps in 'Roman' and 'Freedom Red' poinsettias the growth retardant did not affect the content of endogenous abscisic acid, which is responsible for the closing of stomata, and thus flurprimidol could not influence the transpiration.

In the present study, the measurements of stomatal conductance and transpiration were performed at the beginning of anthesis, so there was a long time from flurprimidol application to the measurements of transpiration. Some studies indicate that the impact of growth retardants on transpiration may depend on the time at which transpiration measurements are performed. For example, Norcin i [17] reported that transpiration rate and stomatal conductance of pruned Euonymus fortunei were reduced three days following flurprimidol application, but eighteen days after treatment stomatal conductance and transpiration rate 
were unchanged in growth retardant treated plants, relative to untreated ones. $\mathrm{Mishra}$ and $\mathrm{Pradhan}$ [38] also demonstrated that in tomato plants transpiration was reduced up to $34 \%$ if its measurements were performed 24 hours after daminozide application, but after five days the reduction of transpiration was only up to $19 \%$.

The present study shows that flurprimidol did not affect transpiration rate per unit leaf area in 'Roman' and 'Freedom Red' poinsettias, but it could reduce whole-plant transpiration due to reduced leaf area.

\section{CONCLUSIONS}

Single foliar flurprimidol application effectively inhibits stem elongation of 'Roman' and 'Freedom Red' poinsettias, but growth retardant doses should be varied depending on poinsettia cultivar. Retardant at 5 $\mathrm{mg} \times \mathrm{dm}^{-3}$ is recommended for 'Roman', but $10 \mathrm{mg} \times$ $\mathrm{dm}^{-3}$ is required for 'Freedom Red' in order to obtain short and well compact plants. Flurprimidol reduced the leaf area and only slightly decreased the bract diameter. Stomatal conductance and transpiration rate per unit leaf area were not affected by growth retardant treatment. Smaller and narrower in width plants treated with growth retardant might have an economic advantage to commercial growers due to increased plant density on greenhouse benches. Thanks to improved plant compactness, intensified green leaf pigmentation, bracts placed on this same level and no leaf abscission in the low portions of plants, flurprimidol treated poinsettias are more decorative and of much higher quality.

\section{Acknowledgments}

The research was supported by the Ministry of Science and Higher Education of Poland as part of the statutory activities of the Research Institute of Horticulture.

\section{REFERENCES}

1. Moe R, Fjeld T, Mortensen LM. Stem elongation and keeping quality in poinsettia (Euphorbia pulcherrima Willd.) as affected by temperature and supplementary lighting. Sci Hortic. 1992; 50(1-2): 127-136. http://dx.doi. org/10.1016/S0304-4238(05)80015-9

2. Lewis KP, Faust JE, Sparkman JD, Grimes LW. The effect of daminozide and chlormequat on the growth and flowering of poinsettia and pansy. HortScience. 2004; 39(6): 1315-1318.

3. Niu G, Heins R, Carlson W. Using paclobutrazol to control height of poinsettia "Freedom". HortTechnology. 2002; 12(2): 232-236.
4. Faust JE, Korczynski PC, Klein R. Effects of paclobutrazol drench application date on poinsettia height and flowering. HortTechnology. 2001; 11(4): 557-560.

5. Currey CJ, Lopez RG. Early flurprimidol drench applications suppress final height of four poinsettia cultivars. HortTechnology. 2011; 21(1): 35-40.

6. Bailey DA, Miller WB. Poinsettia developmental and postproduction responses to growth retardants and irradiance. HortScience. 1991; 26(12): 1501-1503.

7. Lodeta KB, Ban SG, Perica S, Dumičić G, $\mathrm{B} u$ ć a n L. Response of poinsettia to drench application of growth regulators. J Food Agric Env. 2010; 8(1): 297-301.

8. McDaniel GL. Comparison of paclobutrazol, flurprimidol, and tetcyclacis for controlling poinsettia height. HortScience. 1986; 21(5): 1161-1163.

9. Sachs RM, Lang A, Bretz CF, Roach J. Shoot histogenesis: subapical meristematic activity in a caulescent plant and the action of gibberellic acid and Amo-1618. Am JBot. 1960; 47: 260-266. http://dx.doi.org/10.2307/2439605

10. Reed AN, Curry EA, Williams MW. Translocation of triazole growth retardants in plant tissues. J Am Soc Hortic Sci. 1989;114:893-898.

11. Pobudkiewicz A, Nowak J. Response of chrysanthemum (Dendranthema grandiflora Tzvelev) cvs. Altis and Surf to flurprimidol application. J Fruit Ornam Plant Res. 1997; 5: 43-52.

12. Pobudkiewicz A, Nowak J. Effect of flurprimidol and silver thiosulfate (STS) on the growth and flowering of "Prima" lilies grown as pot plants. Acta Hortic. 1992; 325: 193-198.

13. Pobudkiewicz A, Nowak J, Podwyszyńska M, Przybyła A. The effect of growth retardants on growth and flowering of dwarf alstroemeria. Acta Agrobot. 2000; 53(2): 77-83. http://dx.doi.org/10.5586/aa.2000.017

14. Pobudkiewicz A, Podwyszyńska M. The response of Globba winitii (Siam) to application of flurprimidol. Folia Hort. 1999; 11(1).

15. Pobudkiewicz A, Treder J. Effects of flurprimidol and daminozide on growth and flowering of oriental lily "Mona Lisa". Sci Hortic Amst. 2006; 110(4): 328-333. http://dx.doi.org/10.1016/j.scienta.2006.07.019

16. Schuch UK. Response of chrysanthemum to uniconazole and daminozide applied as dip to cuttings or as foliar spray. J Plant Growth Regul. 1994; 13(3): 115-121. http:// dx.doi.org/10.1007/BF00196374

17. N or cin i JG. Growth and water status of pruned and unpruned woody landscape plants treated with Sumagic (uniconazole), Cutless (flurprimidol), and Atrimmec (dikegulac). J Env Hortic. 1991; 9: 231-235.

18. STATISTICA 10.0. StatSoft; 2011.

19. B arrett JE, Nell TA. Transpiration in growth retardant treated poinsettia, bean and tomato (ancymidol, chlormequat, daminozide). Annu Meet Fla State Hort Soc. 1981; 94: 85-87.

20. Sanderson KC, Martin WC, Reed RB. Slowrelease growth retardant tablets for potted plants. HortScience. 1989; 24(6): 960-962. 
21. Pobudkiewicz AK, Goldsberry KL. The optimum growth stage of dwarf carnation for effective Sumagic application. Denver, CO: Colorado State University; 1989. (Research bulletin/Colorado Greenhouse Growers' Association; vol 464).

22. Pobudkiewicz AK, Goldsberry KL. Comparison of dwarf carnation responses to retardants sumagic-TM and Bonzi-TM. Denver, CO: Colorado Greenhouse Growers' Association; 1989. (Research bulletin/Colorado Greenhouse Growers' Association; vol 469).

23. Pobudkiewicz AK, Goldsberry KL. Effect of Cycocel on the height of dwarf carnation "Snowmass". Denver, CO: Colorado Greenhouse Growers' Association; 1989. (Research bulletin/Colorado Greenhouse Growers' Association; vol 473).

24. Pobudkiewicz A, Goldsberry KL. Controlling the growth habit of dwarf pot roses with uniconazole (Sumagic TM). Fort Collins, CO: Colorado State University; 1989. (Research bulletin/Colorado Greenhouse Growers' Association; vol 471).

25. Pobudkiewicz A. Response of seed.propagated geranium (Pelargonium xhortorum L. H. Bailey) to application of flurprimidol. Acta Agrobot. 2000; 53(1): 31-38. http:// dx.doi.org/10.5586/aa.2000.004

26. Pobudkiewicz A. Controlling the growth habit of Streptocarpus hybridus with flurprimidol. J Fruit Ornam Plant Res. 2000;8(1):9-17.

27. Pobudkiewicz A. The response of Cuphea ignea A. DC. to flurprimidol application. Folia Hort. 2000; 12: 99106.

28. Gros s m a n n K. Plant growth retardants as tools in physiological research. Physiol Plant. 1990; 78(4): 640-648. http://dx.doi.org/10.1111/j.1399-3054.1990.tb05254.x

29. Grossmann K, Kwiatkowski J, Siebecker H, J ung J. Regulation of plant morphology by growth retardants: effects on phytohormone levels in soybean seedlings determined by immunoassay. Plant Physiol. 1987; 84(4): 1018-1021. http://dx.doi.org/10.1104/pp.84.4.1018

30. Sterrett JP, Tworkoski TJ, Kujawski PT. Physiological responses of deciduous tree root collar drenched with flurprimidol. J Arboric. 1989; 15: 120-124.

31. Vaigro-Wolff AL, Warmund MR. Suppression of growth and plant moisture stress of forsythia with flurprimidol and XE-1019. HortScience. 1987; 22: 884885.

32. Abdul Jaleel C, Manivannan P, Sankar B, Kishorekumar A, Sankari S, Panneerselv a m R. Paclobutrazol enhances photosynthesis and ajmalicine production in Catharanthus roseus. Process Biochem. 2007; 42(11): 1566-1570. http://dx.doi.org/10.1016/j. procbio.2007.08.006

33. Steinberg SL, Zajicek JM, McFarland MJ. Water relations of Hibiscus following pruning or chemical growth regulation. J Am Soc Hortic Sci. 1991; 116(3): 465-470.

34. Graham JS, Hobbs SD, Zaerr JB. The effect of flurprimidol on bud flush, shoot growth, and on endogenous gibberellins and abscisic acid of Douglas-fir seedlings. J Plant Growth Regul. 1994; 13(3): 131-136. http://dx.doi. org/10.1007/BF00196376

35. Hofman PJ, Menary RC, Clark RJ. Effect of the growth retardant EL500 on growth and plant growth substances in fennel (Foeniculum sp.). J Essent Oil Res. 1992; 4(4): 401-409. http://dx.doi.org/10.1080/10412905.1992.9 698092

36. Ulger S, Akdesir O, Demiral S, Atmaca A. Investigation of the effects of external daminozide application on endogenous hormone levels in "Memecik" olive trees. Acta Hort. 2010; 884: 153-156.

37. Setha S, Kondo S. Abscisic acid levels and antioxidant activity are affected by an inhibitor of cytochrome P450 in apple seedlings. J Hortic Sci Biotechnol. 2009; 84: 340-344.

38. Mishra D, Pradhan GC. Effect of transpiration-reducing chemicals on growth, flowering, and stomatal opening of tomato plants. Plant Physiol. 1972; 50(2): 271-274. http://dx.doi.org/10.1104/pp.50.2.271

\section{Wpływ retardantu wzrostu na wzrost i rozwój Euphorbia pulcherrima Willd. ex Klotzsch}

\section{Streszczenie}

Badanie to zostało przeprowadzone w celu oceny wpływu fluroprimidolu stosowanego dolistnie, jednokrotnie, na morfologię i transpirację poinsecji (Euphorbia pulcherrima Willd. ex Klotzsch) 'Roman' and 'Freedom Red'. Retardant wzrostu fluroprimidol (Topflor $015 \mathrm{SL}$ ) stosowano w stężeniach 5, 10 or $15 \mathrm{mg}$ $\mathrm{dm}^{-3}$, gdy pędy boczne po uszczykiwaniu miały ok. 5 $\mathrm{cm}$ długości. Jednokrotne, dolistne podanie fluroprimidolu było wystarczające do zahamowania wydłużania się pędów poinsecji. Stopień zahamowania wzrostu zależał od odmiany i stężenia retardantu wzrostu. W porównaniu z kontrolą, pędy roślin 'Roman' and 'Freedom Red' traktowanych fluroprimidolem były odpowiednio do $44 \%$ i $37 \%$ krótsze. Żądaną wysokość poinsecji 'Roman' and 'Freedom Red' uzyskano stosując retardant wzrostu $\mathrm{w}$ stężeniach, odpowiednio, 5 i 10 $\mathrm{mg} \mathrm{dm}^{-3}$. Pędy poinsecji opryskiwanej fluroprimidolem były również bardziej sztywne i wyrównane względem siebie, tak więc liście przykwiatowe na roślinie były umieszczone na tym samym poziomie. Średnice poinsecji traktowanych retardantem wzrostu były do $13 \%$ węższe. Powierzchnie liści, długości ogonków liściowych, świeże i suche masy poinsecji 'Roman' and 'Freedom Red' traktowanych fluroprimidolem były znacznie mniejsze w porównaniu z kontrolą. Retardant wzrostu tylko w niewielkim stopniu wpłynął na średnicę liści przykwiatowych obu odmian poinsecji. Rośliny poddane działaniu fluroprimidolu miały 
również intensywniejsze zielone zabarwienie liści. W porównaniu do kontroli, najstarsze liście w dolnych partiach roślin traktowanych retardantem nie opadały. Fluroprimidol nie miał wpływu na przewodność szparkową liści i transpirację obu odmian poinsecji w przeliczeniu na jednostkę powierzchni liścia. $\mathrm{Na}$ roślinach traktowanych fluroprimidolem nie stwierdzono objawów fitotoksyczności liści.

Handling Editor: Elżbieta Weryszko-Chmielewska

This is an Open Access digital version of the article distributed under the terms of the Creative Commons Attribution 3.0 License (creativecommons.org/licenses/by/3.0/), which permits redistribution, commercial and non-commercial, provided that the article is properly cited.

(CThe Author(s) 2014 Published by Polish Botanical Society 